\section{BRAZIULIAN JOURNAL}

OF MEDICAL AND BIOLOGICAL RESFARCH

www.bjournal.com.br
ISSN 0100-879X

Volume 44 (1) 1-83 January 2011

CLINICAL INVESTIGATION

Braz J Med Biol Res, January 2011, Volume 44(1) 16-22

doi: 10.1590/S0100-879X2010007500144

Characterization of alpha thalassemic genotypes by multiplex ligation-dependent probe amplification in the Brazilian population

C.N. Suemasu, E.M. Kimura, D.M. Oliveira, M.A.C. Bezerra, A.S. Araújo, F.F. Costa and M.F. Sonati

The Brazilian Journal of Medical and Biological Research is partially financed by

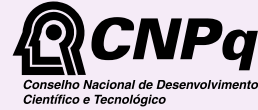

Ministério

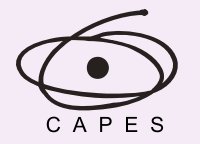

Ministério da Educação

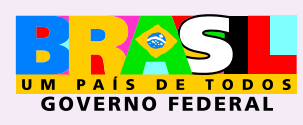

GOVERNO FEDERAL
DFAPESP

Institutional Sponsors
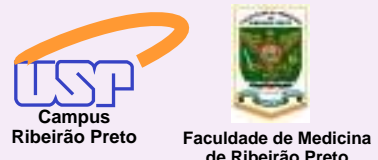

Ф SHIMADZU

GE Healthcare
Hotsite of proteomics metabolomics developped by: 


\title{
Characterization of alpha thalassemic genotypes by multiplex ligation-dependent probe amplification in the Brazilian population
}

\author{
C.N. Suemasu ${ }^{1}$, E.M. Kimura ${ }^{1}$, D.M. Oliveira ${ }^{1}$, M.A.C. Bezerra ${ }^{2}$, A.S. Araújo ${ }^{3}$, \\ F.F. Costa ${ }^{4}$ and M.F. Sonati ${ }^{1}$ \\ ${ }^{1}$ Laboratório de Hemoglobinopatias, Departamento de Patologia Clínica, Faculdade de Ciências Médicas, \\ Universidade Estadual de Campinas, Campinas, SP, Brasil \\ ${ }^{2}$ Centro de Ciências Biológicas, Universidade Federal de Pernambuco, Recife, PE, Brasil \\ ${ }^{3}$ Fundação de Hematologia e Hemoterapia de Pernambuco, Recife, PE, Brasil \\ ${ }^{4}$ Centro de Hematologia e Hemoterapia, Universidade Estadual de Campinas, Campinas, SP, Brasil
}

\begin{abstract}
Alpha-thalassemia is the most common inherited disorder of hemoglobin synthesis. Genomic deletions involving the alpha-globin gene cluster on chromosome $16 \mathrm{p} 13.3$ are the most frequent molecular causes of the disease. Although common deletions can be detected by a single multiplex gap-PCR, the rare and novel deletions depend on more laborious techniques for their identification. The multiplex ligation-dependent probe amplification (MLPA) technique has recently been used for this purpose and was successfully used in the present study to detect the molecular alterations responsible for the alpha-thalassemic phenotypes in 8 unrelated individuals ( 3 males and 5 females; age, 4 months to 30 years) in whom the molecular basis of the disease could not be determined by conventional methods. A total of 44 probe pairs were used for MLPA, covering approximately $800 \mathrm{~kb}$ from the telomere to the MSLN gene in the 16 p13.3 region. Eight deletions were detected. Four of these varied in size from 240 to $720 \mathrm{~kb}$ and affected a large region including the entire alpha-globin gene cluster and its upstream regulatory element (alpha-MRE), while the other four varied in size from 0.4 to $100 \mathrm{~kb}$ and were limited to a region containing this element. This study is the first in Brazil to use the MLPA method to determine the molecular basis of alpha-thalassemia. The variety of rearrangements identified highlights the need to investigate all cases presenting microcytosis and hypochromia, but without iron deficiency or elevated hemoglobin $\mathrm{A}_{2}$ levels and suggests that these rearrangements may be more frequent in our population than previously estimated.
\end{abstract}

Key words: Alpha-thalassemia; Hb H disease; Multiplex ligation-dependent probe amplification; Genetic polymorphisms; Brazilian population

\section{Introduction}

The human alpha $(\alpha)$-globin gene cluster is located on the distal portion (p13.3-pter) of the short arm of chromosome 16 and includes three functional $\alpha$-like protein coding genes $\left(\zeta, \alpha_{2}\right.$, and $\left.\alpha_{1}\right)$, two expressed genes with unknown function $\left(\mu\right.$ and $\left.\theta_{1}\right)$, and three pseudogenes $\left(\psi \zeta, \psi \alpha_{1}, \psi \rho\right)$ arranged in the order $5^{\prime}-\zeta-\psi \zeta-\mu-\psi \alpha_{1}-\alpha_{2}-\alpha_{1}-\psi \rho-\theta_{1}-3^{\prime}(1,2)$. The $\alpha$-globin regulatory elements lie upstream of the start of the $\zeta$-globin gene (10 to $50 \mathrm{~kb}$ ) and consist of four conserved Dnasel hypersensitive sites (HS-48, HS-40, HS-33, and $\mathrm{HS}-10$ ) that bind erythroid-specific transcription factors $(3,4)$. Of these four sites, HS-40 is the only one capable of directing high-level expression of the $\alpha$-globin chains and is thus the major regulatory element ( $\alpha-M R E)(5)$.

Molecular lesions affecting the a-globin genes or their regulatory element ( $\alpha-M R E)$ lead to $\alpha$-thalassemia, an inherited hemoglobin $(\mathrm{Hb})$ disorder characterized by a reduction in or absence of a-globin chain synthesis. Deletions are the major molecular cause of the disease and may affect one or both a-genes in the chromosome (the $\alpha^{+}$and $\alpha^{0}$ forms, respectively) $(1,6)$. The clinical phenotype of carriers varies according to the number of genes affected. Carriers of three functioning globin genes (- $\alpha / \alpha \alpha)$ do not present detectable red blood cell abnormalities or globin-chain imbalance, while carriers of two functioning

Correspondence: M.F. Sonati, Departamento de Patologia Clínica, Faculdade de Ciências Médicas, UNICAMP, Caixa Postal 6111 , 13083-970 Campinas, SP, Brasil. Fax: +55-19-3521-9451. E-mail: sonati@fcm.unicamp.br

Received August 13, 2010. Accepted December 3, 2010. Available online December 17, 2010. Published January $17,2011$. 
$\alpha-g e n e s(-\alpha /-\alpha,--/ \alpha \alpha)$ have mild microcytic, hypochromic anemia with normal hemoglobin $\mathrm{A}_{2}$ levels. Carriers of only one functioning a-gene (--/- $\alpha$ ) present moderate to severe anemia with markedly unbalanced globin-chain synthesis ratios. Failure to inherit any functional $\alpha$-globin genes (--/--) is usually incompatible with life and leads to Hb Bart's ( $\mathrm{Y} 4$ tetramers) hydrops fetalis $(1,7)$.

Although $\alpha$-thalassemia is present throughout the world, its distribution varies greatly among different populations. In Brazil, most of the recognized $\alpha$-thalassemia mutations involve deletions of one $\alpha$-globin gene ( $\alpha^{+}$-thalassemias), although several cases of $\alpha^{0}$-thalassemias have been reported in the literature (8-12). It has been shown that the $-\alpha^{3.7}$ deletion is the most frequent mutation in the Brazilian population, occurring in $20-25 \%$ of the black population in the Southeastern region of the country (13).

The most common $\alpha$-thalassemia deletions can be detected by a single multiplex gap-PCR [i.e., $-\alpha^{3.7},-\alpha^{4.2}$, $-(\alpha)^{20.5}$, --MED, ---SEA, --FIL, -- THAl] (14). However, there are many cases whose iron profile, $\mathrm{Hb} \mathrm{A}_{2}$ and $\mathrm{Hb} F$ levels are normal but whose red blood cells have reduced mean corpuscular volume (MCV) and mean corpuscular hemoglobin $(\mathrm{MCH})$, hematological alterations that are characteristic of defects in hemoglobin synthesis and whose causes remain unidentified. Southern blot and/or FISH have been employed to determine the cause of these abnormalities; however, both techniques are time consuming and labor intensive (15).

Multiplex ligation-dependent probe amplification (MLPA) is a simple technique that is suitable for rapid quantitative analysis and allows the detection of any deletions or duplications in the screened regions. More recently, it has been used to study large alterations in globin genes (15). In the present study, we used this technique to determine the molecular basis of $\alpha$-thalassemic phenotypes in 8 unrelated individuals, 5 of whom had $\mathrm{Hb} \mathrm{H}$ disease.

\section{Patients and Methods}

\section{Patients}

Eight patients of different ethnic backgrounds suspected of having hemoglobinopathies were referred to the UNICAMP Hospital, Campinas, in Southeastern Brazil, for hematological and DNA analysis. Three of them were selected because, although their iron status was normal, they had a thalassemia phenotype (MCV $<70 \mathrm{fl}, \mathrm{MCH}<25 \mathrm{pg}$ ) and structurally intact $\alpha$-globin genes. The other patients had $\mathrm{Hb}$ $\mathrm{H}$ disease, for which it had not been possible to determine the molecular basis as analysis revealed only one mutation (- $a^{3.7}$ deletion). Family analysis was only possible for some patients because samples were not available for all family members. Demographic, hematological and molecular data of patients and relatives are summarized in Table 1.

Red blood cell indices were obtained with an electronic cell counter (Sysmex XE2100, Sysmex, Japan). Hemoglobin evaluation was carried out by electrophoresis on cellulose acetate at alkaline and neutral $\mathrm{pHs}$, and the levels of $\mathrm{Hb} \mathrm{A}_{2}$, $\mathrm{Hb} \mathrm{F}, \mathrm{Hb} \mathrm{H}$, and $\mathrm{Hb}$ Bart's, when these were present, were quantified using cation exchange-high performance liquid chromatography (16) (Variant ${ }^{\mathrm{TM}}$, Bio-Rad Laboratories, USA). Preparations for the detection of $\mathrm{Hb} \mathrm{H}$ inclusions were processed by incubating an aliquot of whole blood for $1 \mathrm{~h}$ at $37^{\circ} \mathrm{C}$ with $1 \%$ brilliant cresyl blue in buffered saline (16).

Table 1. Demographic, hematological and molecular data for the patients and their families.

\begin{tabular}{|c|c|c|c|c|c|c|c|c|c|c|c|c|c|}
\hline Cases & $\mathrm{P} 1$ & $\mathrm{P} 2$ & P3 & PM3 & PB3 & P4 & P5 & P6 & $\mathrm{P} 7$ & PF7 & P8 & PM8 & PF8 \\
\hline Age/Gender & $16 / F$ & $14 / \mathrm{M}$ & $26 / F$ & $44 / F$ & $24 / M$ & $14 / F$ & $30 / \mathrm{M}$ & $23 / F$ & $4 \mathrm{~m} / \mathrm{F}$ & 29/M & $3 / \mathrm{M}$ & $27 / M$ & $30 / \mathrm{M}$ \\
\hline $\begin{array}{l}\mathrm{RBC}\left(10^{6} / \mathrm{mm}^{3}\right) \\
\text { (RF: M: } 4.5-6.1, \mathrm{~F}: 4.2-5.4)\end{array}$ & 5.02 & 4.86 & 4.66 & 5.05 & 5.38 & 5.03 & 5.97 & 5.64 & 5.35 & 6.15 & 6.09 & 4.55 & 6.37 \\
\hline $\begin{array}{l}\mathrm{Hb}(\mathrm{g} / \mathrm{L}) \\
\text { (RF: M: 14-18, F: 12-16) }\end{array}$ & 9.4 & 9.2 & 7.7 & 11.3 & 14.5 & 9.0 & 10.6 & 11.5 & 10.3 & 13.3 & 11.3 & 13.3 & 13.9 \\
\hline $\begin{array}{l}\text { MCV (fl) } \\
\text { (RF: M: 81-99, F: 80-96) }\end{array}$ & 62 & 66.5 & 68.2 & 80.4 & 89.2 & 66.2 & 59.4 & 61.7 & 60.4 & 67.6 & 58.3 & 89.5 & 67.8 \\
\hline $\mathrm{MCH}(\mathrm{pg})(\mathrm{RF}: 27-32)$ & 18.6 & 18.6 & 16.5 & 22.4 & 27 & 17.9 & 18.1 & 20.4 & 19.3 & 21.6 & 18.6 & 29.2 & 21.8 \\
\hline $\mathrm{HbF}(\%)(\mathrm{RF}:<1)$ & 1.0 & 0.6 & 0.8 & 0.2 & - & 1.7 & 0.2 & 0.3 & - & 0.8 & 0.1 & 0.4 & 0.1 \\
\hline $\mathrm{Hb} \mathrm{A}_{2}(\%)(\mathrm{RF}: 1.5-3.5)$ & 1.3 & 1.2 & 1.5 & 2.7 & - & 1.6 & 1.5 & 2.6 & - & 3.1 & 3.0 & 3.4 & 3.0 \\
\hline $\mathrm{Hb} \mathrm{H}(\%)$ & 4.5 & 13.4 & 9.5 & - & - & 6.9 & 10.0 & - & - & - & - & - & - \\
\hline $\mathrm{Hb}$ profile & $\begin{array}{c}\mathrm{A}_{2}, \mathrm{~A} \\
\mathrm{H}+\text { Bart's }\end{array}$ & $\begin{array}{c}\mathrm{A}_{2}, \mathrm{~A} \\
\mathrm{H}+ \\
\text { Bart's }\end{array}$ & $\begin{array}{c}\mathrm{A}_{2}, \mathrm{~A} \\
\mathrm{H}+ \\
\text { Bart's }\end{array}$ & $\mathrm{A}_{2}, \mathrm{~A}$ & $A_{2}, A$ & $\begin{array}{l}\mathrm{A}_{2}, \\
\mathrm{~A}, \mathrm{H}\end{array}$ & $\begin{array}{l}\mathrm{A}_{2}, \\
\mathrm{~A}, \mathrm{H}\end{array}$ & $A_{2}, A$ & Bart's & $\mathrm{A}_{2}, \mathrm{~A}$ & $A_{2}, A$ & $\mathrm{~A}_{2}, \mathrm{~A}$ & $A_{2}, A$ \\
\hline Molecular analysis* & $\begin{array}{c}-\alpha^{3.7} \\
\text { Hetero }\end{array}$ & $\begin{array}{c}-\alpha^{3.7} \\
\text { Hetero }\end{array}$ & $\begin{array}{l}-\alpha^{3.7} \\
\text { Homo }\end{array}$ & $\begin{array}{l}-a^{3.7} \\
\text { Homo }\end{array}$ & $\begin{array}{c}-\alpha^{3.7} \\
\text { Hetero }\end{array}$ & $\begin{array}{l}-\alpha^{3.7} \\
\text { Homo }\end{array}$ & $\begin{array}{l}-\alpha^{3.7} \\
\text { Homo }\end{array}$ & Normal & Normal & Normal & Normal & Normal & Normal \\
\hline Sequencing of $\alpha$-MRE & Hapl A & Hapl D & Hapl A & - & - & Hapl D & Hapl D & Hapl D & Hapl A & - & Hapl A & - & - \\
\hline
\end{tabular}

$\mathrm{P}=$ patients; $\mathrm{PM}=$ patient's mother; $\mathrm{PB}=$ patient's brother; $\mathrm{PF}=$ patient's father; $\mathrm{RBC}=$ red blood cells; $\mathrm{Hb}=$ hemoglobin; $\mathrm{MCV}=$ mean corpuscular volume; $\mathrm{MCH}=$ mean corpuscular hemoglobin; * by multiplex gap-PCR and/or specific PCR; Homo = homozygous; Hetero = heterozygous; $\mathrm{Hapl}=$ haplotype; $\mathrm{RF}=$ reference values; $\mathrm{M}=$ males; $\mathrm{F}=$ females; $\mathrm{m}=$ months. 
Genomic DNA was extracted from peripheral blood samples collected in EDTA using a commercial kit (Blood GenomicPrep Mini-Spin, GE Healthcare, Amersham, UK). Patients in whom no abnormalities were found by multiplex gap-PCR for the common deletions $\left[-\alpha^{3.7},-\alpha^{4.2},-(\alpha)^{20.5}\right.$, --MED, --SEA, --FIL, and -THAl] (14) were screened for common non-deletional mutations ( $\mathrm{Hphl}, \mathrm{Ncol}$ and Tsaudi), after selective PCR amplification and restriction analysis (17). Direct nucleotide sequencing of the $\alpha-M R E$ was performed using primers described elsewhere (18) and an ABI 377 DNAAnalysis System (ABI PRISM ${ }^{\mathrm{TM}} 377$ DNAAutomated Sequencer, Applied BioSystems, USA).

The study was approved by the Ethics Committee (Opinion No. 918/2007, 18/02/2007) of the Universidade Estadual de Campinas and all subjects gave written informed consent to participate.

\section{MLPA reaction}

A commercially available kit was used to screen for copy number variations involving the a-globin cluster on chromosome 16p13.3 (SALSA MLPA kit P140B2 HBA, MRC-Holland, The Netherlands). First, 26 probes included in the commercial kit were used, spanning a 130-kb region of the a-globin gene cluster from gene POLR3K (next to the tip of the short arm of chromosome 16) to the 3' region of the $\alpha_{1}$-globin gene. HS-40 and all the coding genes $(\zeta$, $\alpha_{2}$, and $\alpha_{1}$ ) were targeted (represented as darker arrows in Figure 1A). The probe mix included 12 reference probes targeting chromosomal sites other than those in the $16 \mathrm{p} 13.3$ region, which were used as internal controls to normalize the results for each sample. Eighteen additional synthetic probes described elsewhere (15) were then synthesized to enlarge and refine map deletions and duplications distributed along an 800-kb genomic region from the POLR3K gene that can cause $\alpha$-thalassemias. These oligonucleotides, synthesized in a salt-free environment (25-nmol scale), were from Invitrogen (USA) and were used without further purification. The MLPA reactions using these probes were carried out in two steps (represented as dotted and narrow arrows in Figure $1 \mathrm{~A})$.

A 200- to 250-ng aliquot of DNA sample was used for each subject. Tests were performed with a standard thermocycler (Eppendorf, Germany) according to manufacturer instructions. Amplification products were separated by capillary electrophoresis on a MegaBACE ${ }^{\mathrm{TM}}$ sequencer (GE Healthcare Life Sciences, Sweden) and the results were analyzed with Fragment Profiler $^{\circledR}$ (MegaBACE ${ }^{\mathrm{TM}}$, GE Healthcare Life Science). At least three normal control samples were analyzed with each group of patient samples. Deletions previously confirmed by gap-PCR $\left(-\alpha^{3.7},-(\alpha)^{20.5}\right.$, --SEA, --MED, --FIL) were used as positive controls for the MLPA of the a-globin gene cluster.

\section{MLPA data analysis}

Data from Fragment Profiler ${ }^{\circledR}$ were exported to Microsoft
Excel for analysis. The relative probe signals were determined by dividing the peak height of each amplification product by the total peak height of the reference probes in the probe mix. Each normalized peak was then divided by the average height of the normalized peaks for normal control subjects. The upper threshold for deletions was set at 0.75 , and the lower threshold for duplications at 1.25 . Normal values were defined as being between 0.8 and 1.2. All samples were tested at least twice, and in some cases the same tests were carried out with samples from other members of the families.

\section{Results}

In most diagnostic laboratories, a subset of thalassemia phenotypes for which no molecular defect has been identified by conventional techniques remains uncharacterized. However, thalassemia is still a possibility in these cases since the patients present persisting hematological alterations such as hypochromia and microcytosis. We used MLPA to test DNA samples from eight patients whose hematological alterations could not be explained by conventional analysis of the globin genes.

Five cases with $\mathrm{Hb} \mathrm{H}$ (P1 to P5) were found to have a combination of the $\alpha^{0}$ deletion with the common $\alpha^{+3.7}$ deletion, and 3 other patients were simple $\alpha^{0}$ heterozygous carriers (P6 to P8). Patient 1 (P1) showed a deletion limited to a region containing the upstream regulatory element HS40 (probes 2 and 3). Hence, although the a-globin genes were intact, they were not expressed in this patient. Three individuals (P2, P7, and P8) showed the same type of deletion, in which the region from the telomere to the 5' region of gene $\zeta$ encompassing probes 1 to $9 \mathrm{H}$ (P2 and P7) and 1 to 4 (P8) is absent. Large deletions involving the entire a-globin gene locus, including the a-MRE, were found in 4 other cases (P3, P4, P5, and P6). These encompassed probes 1 to $22 \mathrm{H}, 1$ to $30 \mathrm{H}$ (except $28 \mathrm{H}$ ), 1 to $30 \mathrm{H}$, and 1 to $35 \mathrm{H}$, respectively. A schematic overview of all the deletions is shown in Figure 1A.

In the family analyses, the MLPA assay revealed that the mother and brother of patient 3 were homozygous and heterozygous, respectively, for the common $-\alpha^{3.7}$ deletion (probe $14 \alpha_{2}$ to $13 \alpha_{1}$ ), a result that is in agreement with the multiplex-PCR findings. Patients 7 and 8 had the same deletions as those detected in their parents (Figure 1B).

\section{Discussion}

$\alpha$-Thalassemias are caused by a wide variety of molecular alterations, ranging from small deletions and/or insertions to very large deletions. This diversity of alterations is associated with the presence of several homologous regions, such as the Alu family of repeats, subsegments $X, Y$, and $Z$ (between a-globin genes) and the GAGG motif, that are distributed along the $\alpha$-locus and facilitate homologous and 


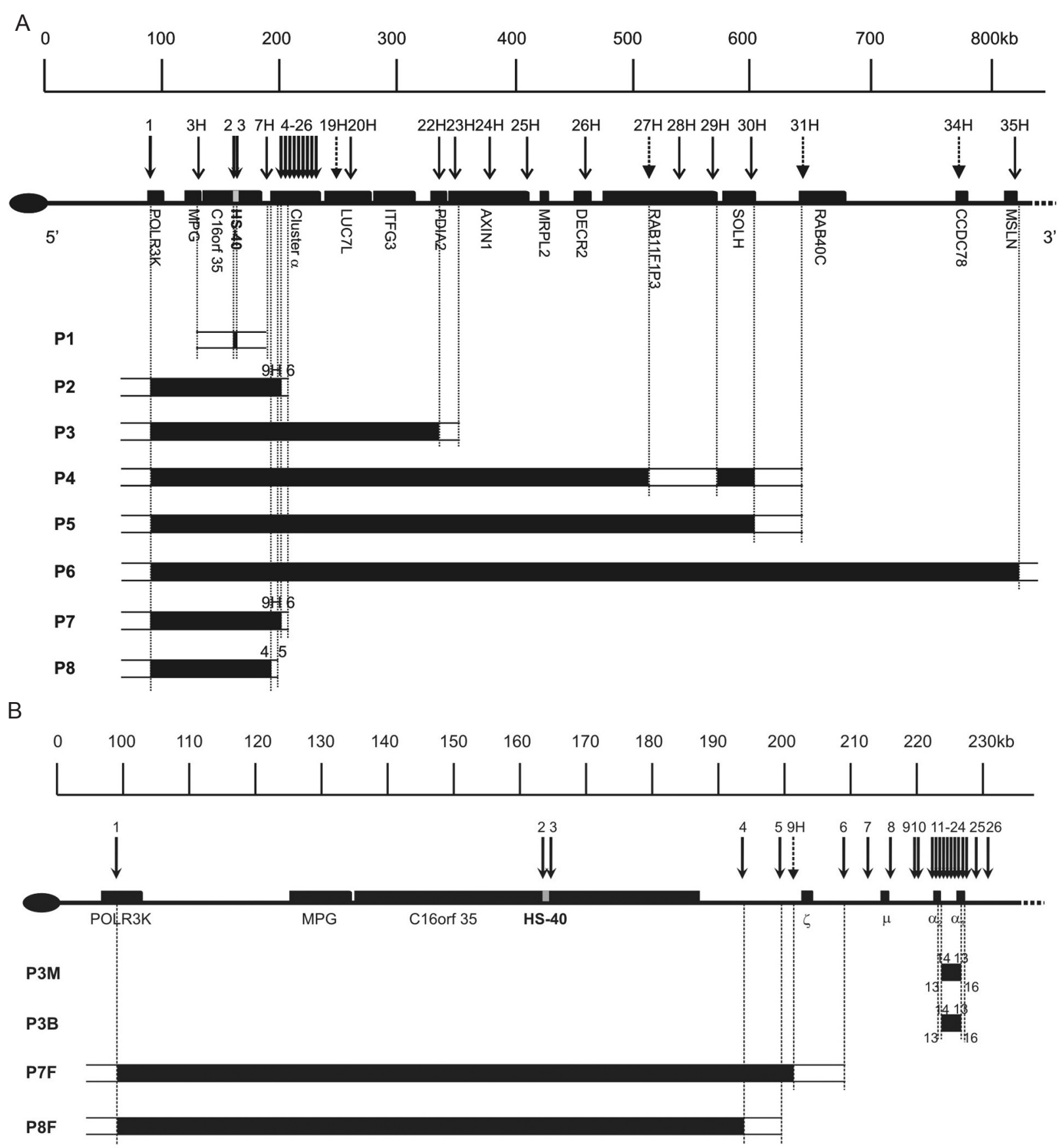

Figure 1. Schematic representation of the short arm of chromosome 16 (16p13.3). A, An 800-kb region containing the $\alpha$-globin gene cluster and HS-40 (adapted from Ref. 15). The oval shape denotes the telomeric repeat region, and the solid boxes denote the genes throughout the regions. The vertical arrows indicate the locations of the probe pairs; the different forms of arrows correspond to each group of probes: darker arrows represent probes included in the kit and dotted and narrow arrows correspond to synthetic probes. The bars below the figure indicate deletions found by multiplex ligation-dependent probe amplification (MLPA) in 8 patients $(P)$. The vertical lines mark the first and last probes deleted. The open boxes indicate the region where deletion breakpoints are expected to be located. $B, A 230-\mathrm{kb}$ region containing the $\alpha$-globin gene cluster and HS-40 (adapted from Ref. 15). The oval shape denotes the telomeric repeat region, and the solid boxes denote the genes throughout the regions. The vertical arrows show the locations of the probe pairs: the narrow arrows correspond to probes included in the kit, and the dotted arrow corresponds to synthetic probe $9 \mathrm{H}$. Probes 13 and 16 included in the kit bind either gene $\alpha_{2}$ or $\alpha_{1}$. The bars below the figure indicate deletions found by MLPA in patient families; the vertical lines mark the first and last probes deleted. The open boxes mark the region where deletion breakpoints are expected to be located. $\mathrm{M}=$ mother; $\mathrm{B}=$ brother; $\mathrm{F}=$ father. 
non-homologous recombination events $(19,20)$. Our results illustrate this diversity. The deletions found in this study are probably different from each other, and the breakpoints are probably unique because the deletions are rare and the patients were unrelated. As the MLPA method has been adapted for high-resolution mapping of deletions, we were able to investigate cases whose molecular alterations could not be identified by conventional techniques (multiplex gapPCR, specific PCR and DNA sequencing).

Four of our patients (P1, P2, P7, and P8) had deletions limited to a region containing the upstream regulatory element; hence, the a-globin genes, although intact, were not expressed. These deletions span a region of at least $0.4 \mathrm{~kb}$ in 1 case and from 95 to $100 \mathrm{~kb}$ in the others [positions 163464-163904, 97000-193847, 97000-202417, and 97000-202417 of the UCSC Genome Browser (21), February 2009, respectively]. Since the first description of a deletion of this type, which removes $62 \mathrm{~kb}$ including the HS-40 element (22), deletions involving this region have been described in more than 20 patients $(10,15,23-31)$. The regulatory element $\alpha-M R E$ behaves as a classic enhancer: its main function in the normal chromosomal environment is to activate and enhance expression from the $\zeta$-globin and a-globin promoters (32). Impairment of this element affects important binding sites for several transcriptional factors (GATA 1, NF-E2 and CACC box) and suppresses $\alpha$-globin gene expression. Like the deletions that remove the a-globin genes, at least some of the $\alpha-M R E$ deletions seem to be the result of recombination events between partially homologous Alu repeats and subtelomeric rearrangements $(2,20)$.

Four other patients (P3, P4, P5, and P6) had large deletions spanning genomic regions of at least 240 , 470,500 , and $720 \mathrm{~kb}$ [positions 97000-334571, 97000$570532,97000-602492$, and 97000-816477 of the UCSC Genome Browser (21), February 2009, respectively] that affect the entire $\alpha$-globin gene cluster and its upstream regulatory element. In these cases, the deletions affected a considerable number of genes and could result in other clinical implications (e.g., mental retardation), as observed in ATR-16 syndromes $(33,34)$. However, no

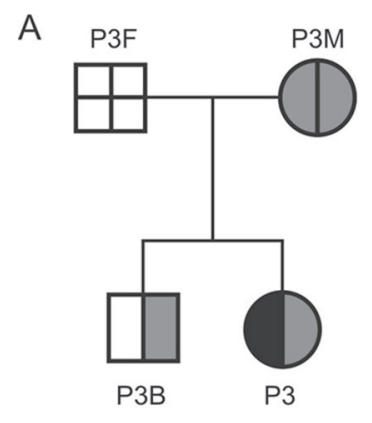

other abnormalities concomitant with $\alpha$-thalassemia were reported in our patients.

Although the exact breakpoint positions and deletion lengths could not be determined at the time of the study, the deletions found in 6 patients (P1, P2, P3, P6, P7, and $\mathrm{P} 8)$ are close in terms of size and genome position to previously described alterations $(10,24,26,27,31)$. Two deletions, found in patients 4 and 5 , showed no resemblance to previously described deletions and are possibly novel. Different from other cases, the $\alpha^{0}$ deletion found in patient 4 may be the result of a breakage in the segment defined by probes 28 and $30 \mathrm{H}$, followed by inversion and deletion of the same segment. The binding site of probe $28 \mathrm{H}$ appears to be preserved since we obtained a normal peak signal for this probe, whereas for the other probes located in cis $(27,29$, and $30 \mathrm{H})$ there was a reduction in peak signal (Figure 1A).

In the family analysis, MLPA assays for the mother and brother of patient 3 revealed an $-\alpha^{3.7}$ deletion in a homozygous and heterozygous state, respectively. Since a sample from the patient's father was not available, it was not possible to conclude whether the $\alpha^{0}$ deletion was inherited from the father or arose in the mother's germ line. The same types of deletions found in patients 7 and 8 were found in their respective fathers, confirming the paternal origin of these mutations (Figures 1B and 2).
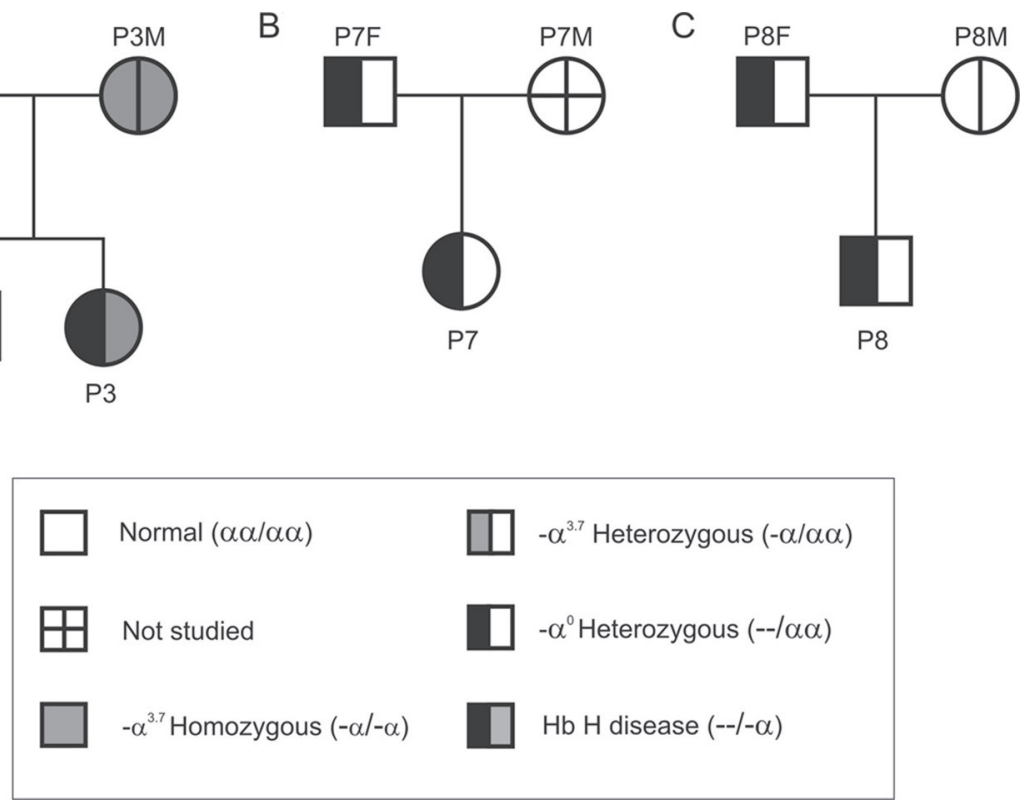

Figure 2. Pedigrees of the three families. $A$, The propositus (P3) had $\mathrm{Hb} \mathrm{H}$ disease $\left(\alpha^{0}\right.$ and $-\alpha^{3.7}$ deletions), while her mother (P3M) and brother (P3B) were homozygous and heterozygous for the $-\alpha^{3.7}$ deletion, respectively. A sample from the father (P3F) was not available. $B$, The propositus (P7) and her father (P7F) were heterozygous for an $\alpha^{0}$ deletion. A sample from the mother (P7M) was not available. $C$, The propositus (P8) and his father (P8F) were heterozygous for an $\alpha^{0}$ deletion, while his mother (P8M) was normal. 
This study is the first in Brazil to use the MLPA method to investigate the molecular basis of $\alpha$-thalassemias. We identified different $\alpha^{0}$ deletions in 8 patients, demonstrating that MLPA is a suitable method for detecting unknown uncommon deletions and is particularly suited to characterizing cases that remain unsolved after standard diagnostic tests. The variety of rearrangements identified in the present study highlights the need to investigate all cases presenting microcytosis and hypochromia but without iron deficiency and elevated $\mathrm{HbA}_{2}$ levels, since these hematological alterations are often interpreted as indicators of iron deficiency and may be the result of patients being inappropriately treated with oral iron therapy.

Carrier diagnosis and molecular characterization of

\section{References}

1. Higgs DR, Vickers MA, Wilkie AO, Pretorius IM, Jarman AP, Weatherall DJ. A review of the molecular genetics of the human alpha-globin gene cluster. Blood 1989; 73: 10811104.

2. Voon HP, Vadolas J. Controlling alpha-globin: a review of alpha-globin expression and its impact on beta-thalassemia. Haematologica 2008; 93: 1868-1876.

3. Tufarelli C, Hardison R, Miller W, Hughes J, Clark K, Ventress $\mathrm{N}$, et al. Comparative analysis of the alpha-like globin clusters in mouse, rat, and human chromosomes indicates a mechanism underlying breaks in conserved synteny. Genome Res 2004; 14: 623-630.

4. Hughes JR, Cheng JF, Ventress N, Prabhakar S, Clark K, Anguita $\mathrm{E}$, et al. Annotation of cis-regulatory elements by identification, subclassification, and functional assessment of multispecies conserved sequences. Proc Natl Acad Sci U S A 2005; 102: 9830-9835.

5. Sharpe JA, Summerhill RJ, Vyas P, Gourdon G, Higgs DR, Wood WG. Role of upstream DNase I hypersensitive sites in the regulation of human alpha globin gene expression. Blood 1993; 82: 1666-1671.

6. Higgs DR. a-thalassemia. In: Higgs DR, Weatherall DJ (Editors), The haemoglobinopathies. London: W.B. Saunders; 1993. p 117-150.

7. Weatherall DJ, Clegg JB. The thalassaemia syndromes. Oxford: Ed. Backwell Science; 2001.

8. Wenning MR, Kimura EM, Costa FF, Saad ST, Gervasio S, de Jorge SB, et al. Alpha-globin genes: thalassemic and structural alterations in a Brazilian population. Braz $J$ Med Biol Res 2000; 33: 1041-1045.

9. Borges E, Wenning MR, Kimura EM, Gervasio SA, Costa FF, Sonati MF. High prevalence of alpha-thalassemia among individuals with microcytosis and hypochromia without anemia. Braz J Med Biol Res 2001; 34: 759-762.

10. Wenning MR, Harteveld CL, Giordano PC, Kimura EM, Saad ST, Costa FF, et al. Hemoglobin $\mathrm{H}$ disease resulting from the association of the -alpha3.7 rightward deletion and the (alpha alpha) MM deletion in a Brazilian patient. Eur $J$ Haematol 2002; 69: 179-181.

11. Cançado RD. Talassemias alfa. Rev Bras Hematol Hemoter 2006; 28: 81-87. unknown and uncommon $\alpha^{0}$ thalassemia deletions are very important for genetic counseling because they allow couples who request prenatal diagnosis and who are at risk for having a severely affected child to make an informed reproductive choice.

\section{Acknowledgments}

Research supported by FAPESP (\#2008/57441-0; \#2010/00560-8) and CNPq. C.N. Suemasu was the recipient of a fellowship from CAPES (\#330030170M6). The authors also thank Dr. Juliana Forte Mazzeu for her Technical Consultancy on the MLPA method.

12. Bezerra MA, Araujo AS, Phylipsen M, Balak D, Kimura EM, Oliveira DM, et al. The deletion of SOX8 is not associated with ATR-16 in an $\mathrm{HbH}$ family from Brazil. $\mathrm{Br} \mathrm{J}$ Haematol 2008; 142: 324-326.

13. Sonati MF, Farah SB, Ramalho AS, Costa FF. High prevalence of alpha-thalassemia in a black population of Brazil. Hemoglobin 1991; 15: 309-311.

14. Chong SS, Boehm CD, Cutting GR, Higgs DR. Simplified multiplex-PCR diagnosis of common southeast Asian deletional determinants of alpha-thalassemia. Clin Chem 2000; 46: 1692-1695.

15. Harteveld CL, Voskamp A, Phylipsen M, Akkermans N, den Dunnen JT, White SJ, et al. Nine unknown rearrangements in 16p13.3 and 11p15.4 causing alpha- and betathalassaemia characterised by high resolution multiplex ligation-dependent probe amplification. J Med Genet 2005; 42: 922-931.

16. Dacie JV, Lewis SM. Practical haematology. 8th edn. Edinburgh: Churchill Livingstone; 1995.

17. Kattamis AC, Camaschella C, Sivera P, Surrey S, Fortina P. Human alpha-thalassemia syndromes: detection of molecular defects. Am J Hematol 1996; 53: 81-91.

18. Harteveld CL, Muglia M, Passarino G, Kielman MF, Bernini LF. Genetic polymorphism of the major regulatory element HS-40 upstream of the human alpha-globin gene cluster. $\mathrm{Br}$ $J$ Haematol 2002; 119: 848-854.

19. Higgs DR, Hill AV, Bowden DK, Weatherall DJ, Clegg JB. Independent recombination events between the duplicated human alpha globin genes; implications for their concerted evolution. Nucleic Acids Res 1984; 12: 6965-6977.

20. Higgs DR, Weatherall DJ. The alpha thalassaemias. Cell Mol Life Sci 2009; 66: 1154-1162.

21. UCSC Genome Browser. http://genome.ucsc.edu/. Accessed June 26, 2010.

22. Hatton CS, Wilkie AO, Drysdale HC, Wood WG, Vickers MA, Sharpe J, et al. Alpha-thalassemia caused by a large ( $62 \mathrm{~kb})$ deletion upstream of the human alpha globin gene cluster. Blood 1990; 76: 221-227.

23. Liebhaber SA, Griese EU, Weiss I, Cash FE, Ayyub H, Higgs DR, et al. Inactivation of human alpha-globin gene expression by a de novo deletion located upstream of the 
alpha-globin gene cluster. Proc Natl Acad Sci U S A 1990; 87: 9431-9435

24. Wilkie AO, Lamb J, Harris PC, Finney RD, Higgs DR. A truncated human chromosome 16 associated with alpha thalassaemia is stabilized by addition of telomeric repeat (TTAGGG)n. Nature 1990; 346: 868-871.

25. Romao L, Osorio-Almeida L, Higgs DR, Lavinha J, Liebhaber SA. Alpha-thalassemia resulting from deletion of regulatory sequences far upstream of the alpha-globin structural genes. Blood 1991; 78: 1589-1595.

26. Romao L, Cash F, Weiss I, Liebhaber S, Pirastu M, Galanello $\mathrm{R}$, et al. Human alpha-globin gene expression is silenced by terminal truncation of chromosome $16 p$ beginning immediately 3 ' of the zeta-globin gene. Hum Genet 1992; 89: 323-328.

27. Flint J, Craddock CF, Villegas A, Bentley DP, Williams HJ, Galanello R, et al. Healing of broken human chromosomes by the addition of telomeric repeats. Am J Hum Genet 1994; 55: 505-512.

28. Flint J, Rochette J, Craddock CF, Dode C, Vignes B, Horsley $\mathrm{SW}$, et al. Chromosomal stabilisation by a subtelomeric rearrangement involving two closely related Alu elements. Hum Mol Genet 1996; 5: 1163-1169.

29. Viprakasit V, Kidd AM, Ayyub H, Horsley S, Hughes J, Higgs DR. De novo deletion within the telomeric region flanking the human alpha globin locus as a cause of alpha thalassaemia. Br J Haematol 2003; 120: 867-875.

30. Viprakasit V, Harteveld CL, Ayyub H, Stanley JS, Giordano PC, Wood WG, et al. A novel deletion causing alpha thalassemia clarifies the importance of the major human alpha globin regulatory element. Blood 2006; 107: 3811-3812.

31. Phylipsen M, Prior JF, Lim E, Lingam N, Vogelaar IP, Giordano PC, et al. Thalassemia in Western Australia: 11 novel deletions characterized by Multiplex Ligation-dependent Probe Amplification. Blood Cells Mol Dis 2010; 44: 146-151.

32. Zhang Q, Reddy PM, Yu CY, Bastiani C, Higgs D, Stamatoyannopoulos $\mathrm{G}$, et al. Transcriptional activation of human zeta 2 globin promoter by the alpha globin regulatory element (HS-40): functional role of specific nuclear factor-DNA complexes. Mol Cell Biol 1993; 13: 2298-2308.

33. Daniels RJ, Peden JF, Lloyd C, Horsley SW, Clark K, Tufarelli $C$, et al. Sequence, structure and pathology of the fully annotated terminal $2 \mathrm{Mb}$ of the short arm of human chromosome 16. Hum Mol Genet 2001; 10: 339-352.

34. Horsley SW, Daniels RJ, Anguita E, Raynham HA, Peden $J F$, Villegas $A$, et al. Monosomy for the most telomeric, gene-rich region of the short arm of human chromosome 16 causes minimal phenotypic effects. Eur J Hum Genet 2001; 9: 217-225. 